\title{
Frutexites encrustations on rugose corals (Middle Devonian, southern Morocco): complex growth of microbial microstromatolites
}

\author{
Michal Jakubowicz $\cdot$ Zdzislaw Belka $\cdot$ \\ Blazej Berkowski
}

Received: 19 April 2013/Accepted: 24 August 2013/Published online: 17 September 2013

(C) The Author(s) 2013. This article is published with open access at Springerlink.com

\begin{abstract}
Microbially induced Frutexites microstromatolites developed on corallites of the Givetian rugose coral "Amplexus" in the sedimentary cover of a submarine volcanic intrusion in the eastern Anti-Atlas of southern Morocco. The corals lived in proximity to submarine hydrothermal fluid emissions. Frutexites form irregular shrubs encrusting external walls of corallites. The shrubs, consisting of alternations of calcitic and hematitic laminae, grew predominantly on abandoned corallites. Some Frutexites grew within the sediment, whereas others developed entirely above the seafloor, or started their accretion in water and continued to grow during burial. Three types of Frutexites encrustations have been distinguished. They look similar macroscopically, but differ significantly in their microstructure and mineralogical characteristics, resulting primarily from spatial and temporal variations in redox conditions. Both hematitic and calcitic laminae are primary features of Frutexites. The shrubs accreted as a result of mineralization of microbial biofilms under fluctuating environmental conditions, caused by changes in $\mathrm{pH}, \mathrm{Fe}^{2+}$-supply and/or oxygenation, presumably related to discharges of reducing hydrothermal fluids. The calcitic
\end{abstract}

\author{
M. Jakubowicz ( $\square)$ \\ Institute of Geoecology and Geoinformation, Adam Mickiewicz \\ University, ul. Dzięgielowa 27, 61-680 Poznań, Poland \\ e-mail: mjakub@amu.edu.pl \\ Z. Belka \\ Isotope Laboratory, Adam Mickiewicz University, \\ ul. Dzięgielowa 27, 61-680 Poznań, Poland \\ e-mail: zbelka@amu.edu.pl \\ B. Berkowski \\ Institute of Geology, Adam Mickiewicz University, \\ ul. Maków Polnych 16, 61-606 Poznań, Poland \\ e-mail: bbrk@amu.edu.pl
}

laminae are interpreted to have formed due to activity of heterotrophic (mainly sulphate-reducing) microbes, whereas the hematitic laminae developed as a result of enhanced activity of nitrate-reducers or due to periodical passive mineralization of biofilms with iron. Cathodoluminescence data provide evidence that the nitrate and sulphate reduction preceded the $\mathrm{Mn}(\mathrm{IV})$ and $\mathrm{Fe}(\mathrm{III})$ reduction, presumably due to increased accumulation of organic matter and a high stability of the iron oxides present.

Keywords Frutexites - Microstromatolites .

Microbialites · Iron oxides · Authigenic carbonates .

Devonian $\cdot$ Morocco

\section{Introduction}

Microbial-derived fabrics embedding or encrusting coral skeletons are common constituents of fossil and modern coral reefs and bioherms (e.g., Pratt 1984; Riding 2000). The development of various types of microbialites is most often interpreted to have taken place in the photic zone, and thus to be indicative of relatively shallow-water settings (Pratt 1984; Guo and Riding 1992; Olivier et al. 2011). Examples of corals encrusted by microbialites from deepwater environments are, in turn, sparse, as such environments are usually nutrient-poor and oxygen-depleted, so that they are rarely favorable for the development of rich coral assemblages (see, among others, Stanley and Cairns 1988).

Frutexites Maslov 1960, also referred to as ferruginous or manganiferous microstromatolites (e.g., Szulczewski 1963; Hofmann 1969; Horodyski 1975), are arborescent, finely laminated to opaque structures consisting of iron 
and/or manganese oxides and calcite; they are known from Proterozoic to Cretaceous marine carbonates (Hofmann 1969; Mišík and Aubrecht 2004; Reolid and Molina 2010). The origin of Frutexites remains a matter of ongoing controversy, as they have no obvious modern marine analogues; the only reports of contemporary, subfossil Frutexites shrubs come from some alkaline lakes (Kaźmierczak and Kempe 2006; Kaźmierczak et al. 2011), and similar structures have been reported from modern deserts (desert varnish; Krumbein and Jens 1981), terrestrial caves and tunnels (Rodríguez-Martínez et al. 2011a) and hot springs (black travertine shrubs; Chafetz et al. 1998). In addition, numerous examples of calcitic microstromatolites are morphologically similar to Frutexites, but lack Fe- and Mn-enrichment (e.g., Chafetz and Folk 1984; Chafetz and Guidry 1999), which further extends the variety of non-marine settings favoring the development of Frutexites-like structures. This makes the lack of modern marine analogues of Frutexites columns somewhat puzzling and difficult to explain.

Although fossil examples of Frutexites have been reported from various depths, ranging from shallow-marine settings to deep-water environments, they all have several features in common. Generally, Frutexites seem to have preferred low-energy environments, characterized by low sedimentation rates and often limited availability of oxygen; they are consequently commonly found on the bottoms of deep, dysaerobic basins (Playford et al. 1976; Tsien 1979; Böhm and Brachert 1993; Reitner et al. 1995; Mamet and Préat 2006; Woods and Baud 2008; Lazăr et al. 2012), not uncommonly in association with hardground surfaces (Mišík and Aubrecht 2004; Reolid and Nieto 2010). Where present in shallow-water settings, in turn, Frutexites are typically limited to cryptic environments, such as such as small cavities and sheet cracks (Hofmann 1969; Horodyski 1975; Walter and Awramik 1979; Myrow and Coniglio 1991). Frutexites shrubs are rarely associated with contemporaneous benthic metazoans, although in some cases they encrusted other organisms after their death (Préat et al. 2008; Reolid and Molina 2010), and, occasionally, were overgrown themselves by foraminifera (Reolid and Molina 2010; Rodríguez-Martínez et al. 2011b). Hence, the presence of hostile, oligotrophic conditions is often regarded a prerequisite for the development of Frutexites in marine settings.

Given the superficial resemblance of Frutexites to abiotic dendrites, it has been proposed that they could have formed due to purely abiotic processes (Wendt 1970). The growing evidence for the involvement of microbes in mineral precipitation (e.g., Buczynski and Chafetz 1991; Frankel and Bazylinski 2003) and the growing number of reports of microbial-associated fossils found in Frutexites and Frutexites-like structures (e.g., Horodyski 1975;
Chafetz et al. 1998) have, however, led to the wide acceptation of the hypothesis that Frutexites grew as a result of microbial activity (e.g., Myrow and Coniglio 1991; Böhm and Brachert 1993; Reolid 2011). Yet, the specific types of microbes involved, as well as the primary composition of the shrubs remains a matter of discussion. Whereas early workers proposed that Frutexites-forming organisms were cyanobacteria (Maslov 1960; Szulczewski 1963; Walter and Awramik 1979; Nicoll and Playford 1993) or other phototrophic microbes (Myrow and Coniglio 1991), others disagreed, pointing at the common presence of Frutexites in deep-water or cryptic habitats (Tsien 1979; Böhm and Brachert 1993; Reolid and Nieto 2010; Reolid 2011). Instead, it has been proposed that Frutexites formed as a result of the activity of iron bacteria (Playford et al. 1976; Chafetz et al. 1998), but the role of various microbes and the exact mechanism of iron precipitation are still poorly understood. While some studies carried out in past two decades shed some light on this issue (Mamet et al. 1997; Mamet and Préat 2006; Lazăr et al. 2012), none of the models provides a plausible explanation for the internal structure of Frutexites and, more particularly, for the intimate association between the iron-rich and calcitic laminae.

The objective of the present study was to investigate the origin of Frutexites shrubs encrusting corallites of the deep-water rugose coral "Amplexus" florescens from the Middle Devonian of the Hamar Laghdad area (southern Morocco). Microfacies investigations, including application of cathodoluminescence, provided information on the time relationship between Frutexites formation and the various microbial processes associated with progressive decomposition of organic matter. A model is proposed in which the textural features of Frutexites, as well as the environmental setting during its formation, is explained by the activity of heterotrophic (mainly sulphate-reducing) microbes, alternating with stages of passive microbe mineralization with iron or enhanced activity of nitratereducing, iron-oxidizing microbes.

\section{Geological background}

The study area is located in the Devonian Hamar Laghdad ridge (eastern Anti-Atlas, southern Morocco), about $16 \mathrm{~km}$ SE from Erfoud (Fig. 1a, c). The ridge is famous for its approximately 50 spectacular conical mud mounds (e.g., Brachert et al. 1992; Belka 1998; Aitken et al. 2002), termed the Kess-Kess mounds, and the occurrence of methane-seep deposits (Peckmann et al. 1999; Cavalazzi et al. 2007). During the Devonian, the Anti-Atlas formed a fragment of a wide shelf, bordering the NW margin of Gondwana (Wendt 1985). Its depositional and tectonic 
evolution was controlled by regional, E-W-trending strikeslip faults, which influenced the subsidence pattern and occasionally acted as sites of volcanic eruptions (Belka et al. 1997). The Hamar Laghdad ridge constitutes a remnant of a seafloor elevation that formed during the Early Devonian due to a submarine eruption of peperites and volcaniclastics (Belka 1998; Aitken et al. 2002). The elevation, located in a relatively deep-water (hemipelagic), aphotic environment was subsequently colonized by a rich fauna dominated by crinoids and brachiopods, resulting in the accumulation of thick bioclastic limestones. Reactivation of the magmatic processes during the Emsian led to the formation of synsedimentary faults (Belka 1998). These served as pathways for the migration of hydrothermal fluids to the seafloor, and the Kess-Kess mounds started to grow at the vent sites. According to Belka (1998) and Mounji et al. (1998), the carbonates precipitated from brines comprising a mixture of hydrothermal fluids and seawater. The vent fauna, restricted to chimneys and zones around the vent outlets, was dominated by rugose and tabulate corals, trilobites, gastropods, and locally by ostracods (Berkowski 2004; Belka and Berkowski 2005). In some parts of the Hamar Laghdad, the hydrothermal activity continued also during the Eifelian and Givetian, resulting in the formation of small mud mounds and hydrocarbon seep deposits (Peckmann et al. 1999; Berkowski 2006; Cavalazzi et al. 2007; Olempska and Belka 2010).

\section{Materials and methods}

The Frutexites encrustations are found on "Amplexus" corals, which form several irregularly distributed coral "meadows' within a relatively small, Givetian (disparilis Zone) mud mound located in the eastern part of the Hamar Laghdad (Berkowski 2006; Fig. 1b, c). The "Amplexus" occurrences are irregularly distributed around what seems to constitute a massive, microsparitic 'core' of the buildup (Berkowski 2006). The original distribution of the 'meadows' within the mound is, however, difficult to reconstruct due to significant post-depositional tectonics that affected the buildup (Jakubowicz et al. 2013). The Frutexites-bearing limestones are patchily distributed within the investigated "Amplexus" assemblages, without a distinct distribution pattern with regard to the boundaries of the meadows or the mud mound as a whole. In fact, the carbonate samples with the Frutexitesencrusted and Frutexites-lacking "Amplexus" corallites were commonly found in close proximity to each other within individual coral assemblages, and often microscopic investigation was required to distinguish between Frutexites-bearing and Frutexites-lacking limestones.

The material under study was collected during the field expeditions of 2004 and 2012. A total of 55 thin-sections and 17 polished slabs have been investigated. In order to distinguish among different opaque minerals, the thinsections have been analyzed using both transmitted and reflected light microscopy. Selected samples have also been studied with cathodoluminescence using a Cambridge luminoscope system CL-8200 ('cold cathode' type), operating under $14-16-\mathrm{kV}$ accelerating voltage and $300 \mu \mathrm{A}$ beam current at the University of Wrocław (Poland). The chemical composition and microstructure of Frutexites and their host limestones were examined under $15-\mathrm{kV}$ accelerating voltage with a scanning electron microscope (SEM) Hitachi S-3700N equipped with EDS-analyser Noran SIX. The SEM-EDS analyses were performed on polished thinsections, which had been etched in $5 \%$ formic acid for $10 \mathrm{~s}$ prior to observation in order to emphasize micromorphological features.

\section{Host carbonates}

The "Amplexus"-containing carbonates of the Givetian mound are mainly packstones to wackestones; the great majority of the original carbonate mud has been recrystallized to microspar. Frutexites are hosted by carbonates characterized by strong enrichment in iron oxides, which occur in the form of subhedral to euhedral crystals scattered within the microspar, dendrites developed along some fractures and, most conspicuously, within the Frutexites encrustations on coral skeletons. Other fossils are rare and include mainly small gastropods and some crinoid and tabulate fragments. Cement-filled cavities constitute locally a considerable volume of the rock, although the individual cavities tend to be relatively small (up to a few $\mathrm{cm}$ ). The first, early marine (non-luminescent) calcite phase is developed as bladed calcite crystals, and the largest volume of the cavities is filled with bright to dull luminescent, granular blocky spar.

The Givetian carbonates that contain "Amplexus" corals devoid of Frutexites encrustations are also poor in fossils other than the rugose corals and are enriched in iron oxides, which may be present either in the form of small crystals that are irregularly distributed within the matrix, or as thin iron-rich rims on corroded coral skeletons (Fig. 2f, g). In contrast to the limestones hosting Frutexites- "Amplexus" associations, however, the volumetrically dominant cement generation occluding numerous, large cavities is here developed as a cloudy, radial fibrous cement, whereas the bladed-to-blocky calcite spar fills only the central parts of the pores. Some of the iron-rich rims have a microstromatolitic fabric (Fig. 2h), but they never form well-developed Frutexites shrubs. It is interesting to note that the iron-rich rims are present on external coral walls exclusively at their contact with radial-fibrous cement, whereas 

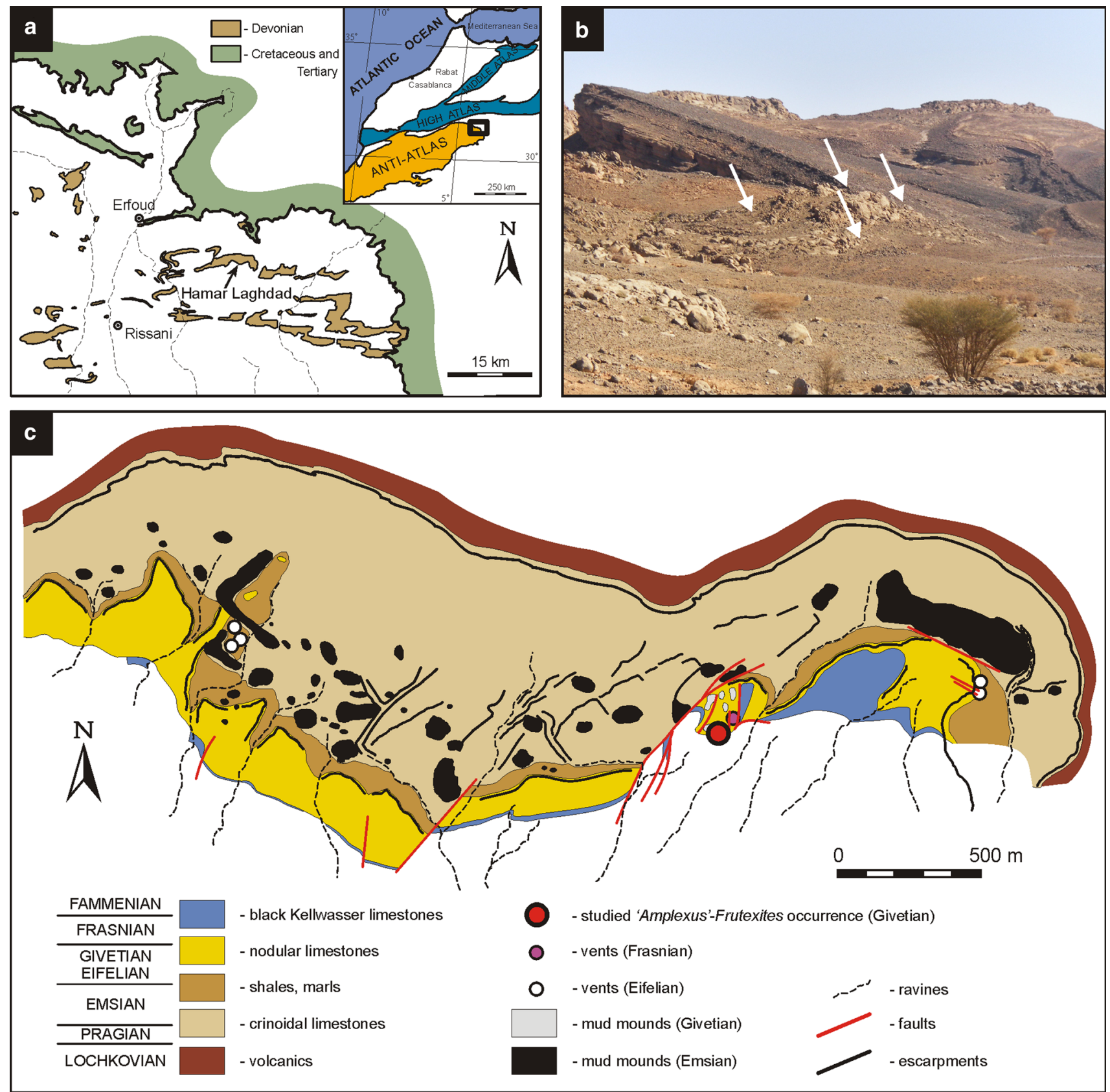

Fig. 1 a Simplified geological map of the eastern Anti-Atlas, showing the distribution of the Devonian rocks and the location of the Hamar Laghdad (from Belka 1998). The inset shows the regional geology and the location of the study area. b The Givetian mud

they are lacking where the corallites are surrounded by microsparitic sediment.

\section{"Amplexus" corals}

In the Hamar Laghdad area, the "Amplexus" corals form rich and mostly monospecific, spot assemblages within the mound with the occurrences of the "Amplexus"-Frutexites associations (arrows). c Geological map of the Hamar Laghdad. The location of the Givetian mound containing the "Amplexus"-Frutexites associations is indicated
Lower and Middle Devonian carbonates. Geological and isotope data show that the assemblages were associated with the areas affected by hydrothermal venting or hydrocarbon seepage (Berkowski 2006; Jakubowicz et al. 2013). It is important to note, however, that Frutexites have been found to encrust "Amplexus" corallites in a single Givetian mound only (assemblage $C$ in Jakubowicz et al. 2013). 
The taxonomy of the "Amplexus" corals has been dealt with by Berkowski (2006), who identified the species as "Amplexus" florescens Pocta, 1902. The corals are relatively large (up to $2 \mathrm{~cm}$ in diameter and $15 \mathrm{~cm}$ in length in mature growth stages) and characterized by scolecoid (worm-like) or cylindrical shapes. The corallites are characterized by a strongly simplified architecture, with thin walls, very short, amplexoid septa and flat, sparsely spaced tabulae. Such a morphology of the skeleton is generally attributed to species living in quiet (usually deep) water settings in the presence of factors favoring the ability to secret a skeleton rapidly, e.g., in response to sinking into soft sediment or submarine fluid seepage (Jakubowicz et al. 2013). The corallites are densely packed, forming assemblages of up to 80 individuals per $100 \mathrm{~cm}^{2}$, and appear locally to have been post mortem displaced, presumably as a result of sediment instability. In some instances, the coral skeletons have been damaged and sediment injections took place through discontinuities in the walls (Figs. 2e, 3b); in other cases only isolated coral fragments are present in the microspar (Fig. 2c). Most commonly, however, the coral walls are intact, and the coral calices have been filled with micritic sediment, whereas the intertabular spaces are now occupied by several generations of sparry cements.

\section{Frutexites encrustations}

\section{General features}

The Frutexites encrustations found on "Amplexus" corals are highly variable with respect to both their external shape and their textural and petrological characteristics. Nevertheless, some general features are common to the majority of these structures. Macroscopically, Frutexites are visible as thin, intricate and dendrite-like shrubs surrounding the corallites, with individual columns up to a few $\mathrm{mm}$ wide and $1 \mathrm{~cm}$ long (Fig. 2a). The large columns are conspicuous due to their dark-brown to black color, contrasting with the surrounding light-brown microspar. Where present, Frutexites encrusted usually all available surfaces of the "Amplexus" skeletons. Most often such surfaces were, however, apparently limited to outer walls of the corallites, and Frutexites encrustations are lacking not only in isolated, spar-filled intertabular spaces, but also in calices filled with microspar. The only exceptions are places where the corallite walls had been broken, and in such instances Frutexites developed also on the inner walls (Figs. 2d, 3b). It is noteworthy that no Frutexites shrubs occur on the external walls at places where two neighboring corallites adhere to each other (Fig. 2b). A characteristic feature of the Frutexites under study is that they are rarely developed on skeletal elements or bioclasts other than those of
"Amplexus" skeletons; even in the sparse examples of Frutexites settled on crinoid or tabulate fragments, the encrustations are usually poorly developed and limited to a few laminae, failing to form well-defined columns. Interestingly, the Frutexites microstromatolites have, however, never been found on gastropod or styliolinid fragments, despite the common availability of such bioclasts in the close proximity of the Frutexites shrubs.

The growth of the Frutexites shrubs in the Givetian mud mound started usually as a single layer, often entirely surrounding a corallite (Fig. 2e). This crust, typically more or less constant in thickness (usually less than $200 \mu \mathrm{m}$ ), consists either of bright-yellow to brownish calcite with some scattered hematite and pyrite crystals, or entirely of semi-translucent to opaque hematite. The initial layer became covered by progressively more undulating laminae, parts of which grew apparently faster than the adjacent areas and thus formed eventually the typical Frutexites columns. The individual columns typically expand distally and show one dominant growth direction, which, however, often changed during the Frutexites development. The columns were almost without exception roughly perpendicular to the coral wall during their early growth, but commonly the longer axes of large Frutexites shrubs became increasingly bent (Fig. 3a) and eventually could merge with one another. A characteristic feature is that subordinate branches digitate commonly from the columns, thus, depending upon the size, shape and number of the digitations, forming characteristic arborescent to dendritic growth forms (Figs. 3a, 5c, 6a).

\section{Frutexites types}

Based on microfabric and mineralogical characteristics, three main types of Frutexites encrustations can be distinguished. The development of these types, conceptually referred here to as the type 1, type 2 and type 3 Frutexites, is clearly related to the textural properties of the carbonates in which they are embedded, whereas they do not show any regular large-scale distribution patterns within the "Amplexus" occurrences or within the mud mound as a whole. The type 1 and type 3 forms are actually the most extreme forms at both sides of the wide range of textures observed in investigated Frutexites, whereas the type 2 form constitutes a mixture of features typical of the two other types.

\section{Type 1 Frutexites}

Type 1 Frutexites, the macroscopically most conspicuous form, is characterized by a high content of iron oxides, resulting in a largely opaque to semi-translucent (brownish to reddish in color) and clotted (micropeloidal) appearance 

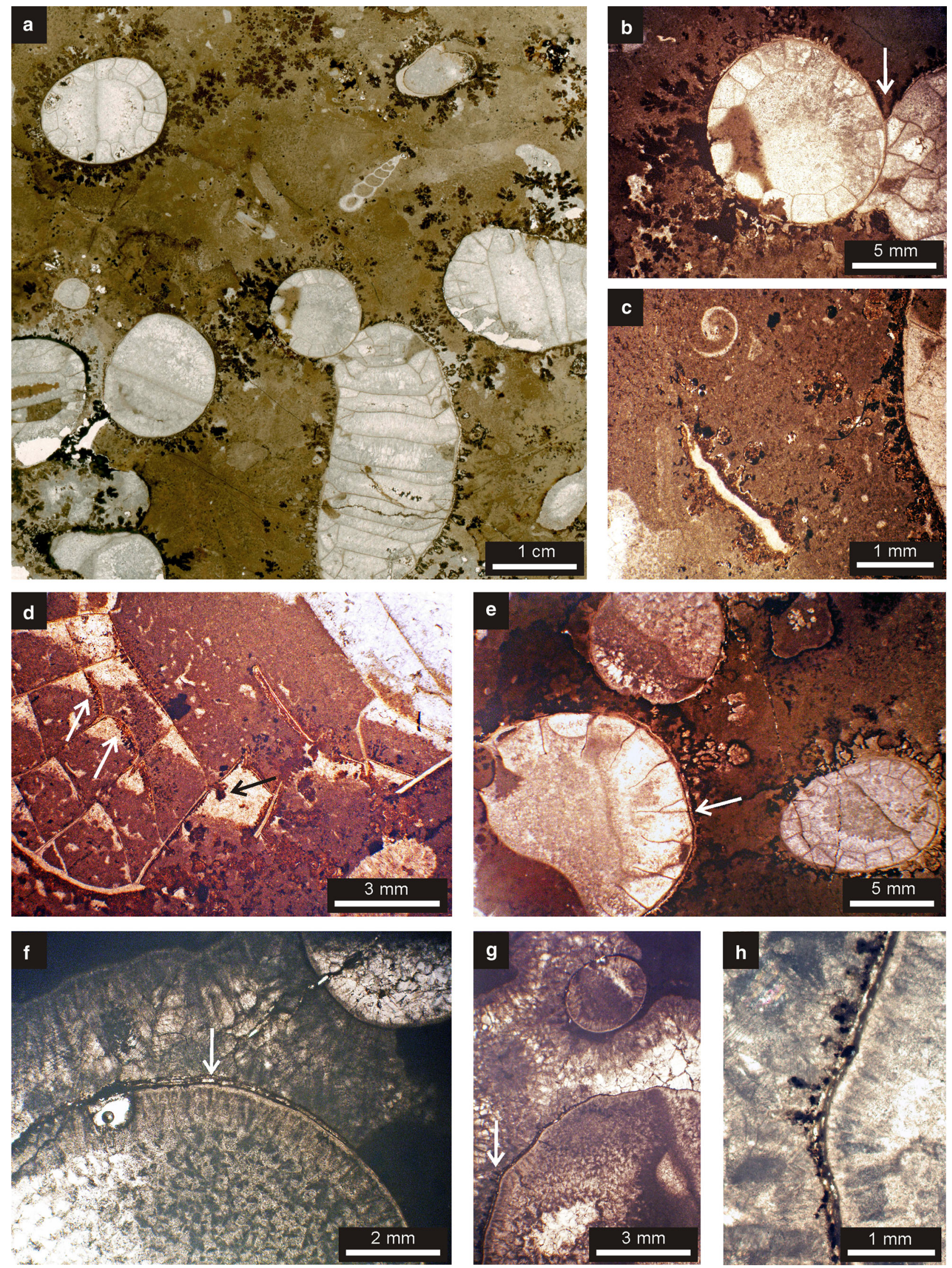
4Fig. 2 a Entire thin-section view of the limestone containing the "Amplexus"-Frutexites association. b Close-up of the Frutexitesencrusted "Amplexus" corallite (center of Fig. 2a). Note the absence of Frutexites on the corallite wall where two corallites are fused. c Frutexites developed on a corallite wall (right) and an isolated coral fragment (left). Note that Frutexites did not encrust the gastropod shell (upper left). d Growth of Frutexites on internal elements of the corallite, made possible by the damage of the corallite wall. e Frutexites-encrusted "Amplexus" specimens. The initial growth of the encrustations as a single layer entirely surrounding the corallite is well visible (arrow). f Frutexites-lacking subfacies of the "Amplexus"-rich limestone. Note the predominance of the radialfibrous cement and the presence of thin, iron-rich coatings on external corallite walls at their contacts with the spar-filled cavities. g "Amplexus" corallites devoid of Frutexites encrustations. The external walls of the corallites are covered by thin coatings, consisting of a few alternations of calcite- and iron-rich laminae and locally forming poorly developed columns (arrow; see Fig. $2 \mathrm{~h}$ for a closeup). h Close-up of the arrowed area of Fig. $2 \mathrm{~g}$, showing small projections of the iron-rich coatings, which failed to turn into welldeveloped Frutexites

(Fig. 3a-e, g). A distinctive feature of this type is that it is always embedded in microsparitic sediment, and that it never occurs in spar-filled cavities. The iron oxides are typically patchily distributed in the form of irregular, micropeloidal aggregates of very fine crystals, making type 1 Frutexites cloudy in appearance, although in places relatively large, euhedral crystals are present as well (Fig. 3g). Reflected-light petrographic investigations and SEM-EDS analyses (Fig. 4b) indicate that the iron oxides are predominantly hematite; only the outermost parts of crystals were often secondarily altered to goethite. Manganese oxides constitute only minor parts of the Frutexites structures. Although the internal structure of type $1 \mathrm{Fru}$ texites is not easily traceable due to the ubiquitous presence of opaque iron minerals, it can be noticed that the spaces between hematitic aggregates are filled either by the surrounding microsparitic sediment or by characteristic, honey-colored to brownish fine calcite spar (Fig. 3d, e, g). In some cases, a distinct lamination of the shrubs is also present (Fig. 3d). Locally, large portions of sediment are trapped between the corallite walls and the initial layers of the Frutexites encrustations (Fig. 3c). When observed under cathodoluminescence, type 1 Frutexites are rather poorly defined against a background of dully luminescent, microsparitic sediment, and show typically patchy luminescence patterns, with bright-orange domains scattered within a non- to dully luminescent 'matrix' (Fig. 3f, h).

\section{Type 2 Frutexites}

Type 2 Frutexites includes specimens consisting of a first, relatively thick (up to $300 \mu \mathrm{m}$ ), clear, sparry calcitic layer, followed by numerous alternations of fine (typically several to a few tens of $\mu \mathrm{m}$ thick), hematitic and calcitic laminae (Figs. 5a, b, f, 6c). The initial layer is characterized by the absence of incorporated matrix material and by a low content of iron oxides, which are present only as some disseminated, euhedral crystals. This layer has locally a roughly constant thickness, but up to $500 \mu \mathrm{m}$ long projections are also common (Figs. 5a-c, 6c, e). Cathodoluminescence shows that the layer has a peculiar cementation pattern, with a first, non- or dull-luminescent cement generation rimming the substrate (corallite) and the roof of the layer (typically made by a first hematitic lamina), and following bright-to-dull cement generations growing towards its center (Fig. 6a-f). The alternations of hematitic and calcitic laminae form usually a characteristic series of regularly spaced, crescent-shaped units ('chambers' sensu Myrow and Coniglio 1991; Fig. 5d-f), the composition of which differs from place to place. Most commonly, the chambers are made of honey-colored to brownish calcite with an admixture of the surrounding microsparitic matrix, whereas the thin intervals separating the 'chambers' are composed of hematite (Fig. 5e). Nevertheless, an opposite pattern, i.e., Frutexites with thick hematite-dominated and thin calcitic intervals is also present (Fig. 5f). In addition, in some rare instances the lamination can be observed only due to the presence of alternations of orange microsparitic and whitish sparry intervals, whereas laminae of iron oxide are lacking. The opaque, hematitic units are occasionally spotted with small, irregular or needle-shaped pores filled with clear calcite spar (Figs. 5e, f, 7c, d). The calcitic laminae, in turn, are typically rather homogeneous in appearance and consist of microspar to small, granular spar crystals, but without the fibrous crystal bundles observed in other studies of Frutexites shrubs (e.g., Myrow and Coniglio 1991; Böhm and Brachert 1993), nor have filamentous or rod-shaped structures (cf. Chafetz et al. 1998; Lazăr et al. 2012) been observed under SEM in the calcitic and hematitic parts of the Frutexites shrubs (Fig. 4a). Both these facts, however, can be attributed to the advanced diagenesis experienced by the investigated carbonates, since they have been subjected to a maximum burial temperature of approximately $200{ }^{\circ} \mathrm{C}$ (Belka 1991).

\section{Type 3 Frutexites}

At the extreme end of the wide range of the observed Frutexites structures is mostly transparent type 3 Frutexites, consisting predominantly of numerous alternations of calcitic laminae which lack any admixture of sediment (Fig. 7a-h). Opaque hematitic laminae may occur, but they are comparatively rare in this type, and the lamination is visible mainly due to the variations in color of the successive calcitic laminae, ranging from brownish or honeycolored to almost colorless (Fig. 7b-e). In places, rare, 

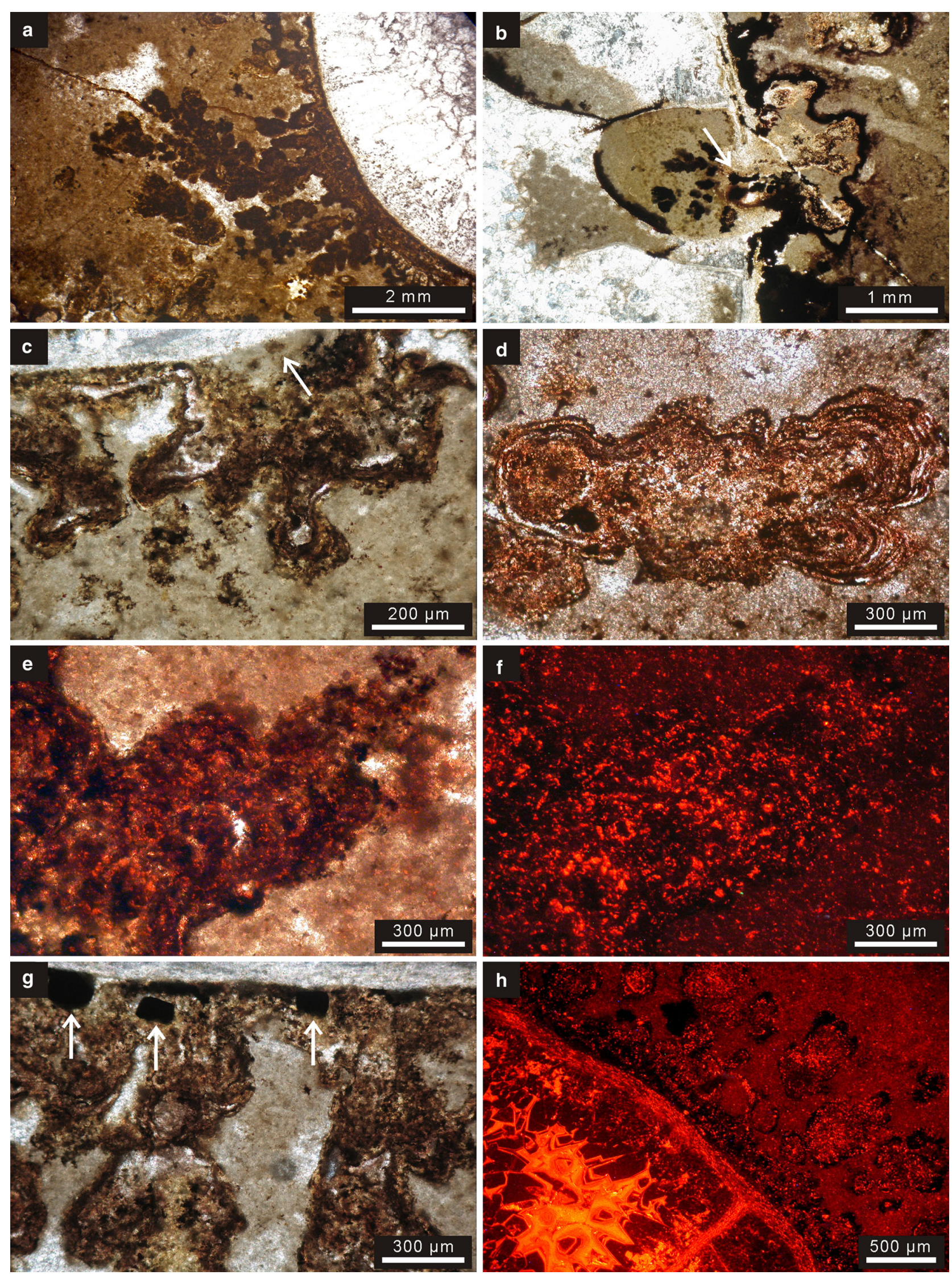
4Fig. 3 Type 1 Frutexites. a Characteristic appearance of type 1 Frutexites forming an irregular, non-laminated, opaque to semitranslucent shrub. b Frutexites developed within a corallite where the corallite wall had been broken (arrow). c Frutexites with a distinct sediment intercalation between the actual shrub and the encrusted corallite (arrow). The stratigraphic top is towards the reader. d Example of sediment-hosted Frutexites with clear lamination. e Close-up of characteristic type 1 Frutexites, with poorly defined lamination and a clotted internal structure caused by the abundant presence of iron oxides. f Cathodoluminescence view of Frutexites shown in Fig. 3e. Note the presence of irregularly distributed domains characterized by different luminescence responses. $g$ Non-laminated, semi-translucent Frutexites with some scattered large hematite crystals (arrows). h Cathodoluminescence view of irregular Frutexites encrusting an "Amplexus" corallite. Note the contrasting, regular non(dull)-to-bright-to-dull luminescence pattern of cements within the corallite, typical of precipitation under progressive burial

small pyrite crystals can be observed within the calcitic units. In some cases, the columns appear almost devoid of hematite, and then can be distinguished from 'non-Frutexites' microstromatolites only on the basis of their close spatial relationship with the actual iron-rich shrubs (Fig. 7e). Type 3 Frutexites includes both forms surrounded by sparry calcite crystals (Fig. 7a, b, g) and shrubs embedded in microsparitic sediment (Fig. 7c-e). When
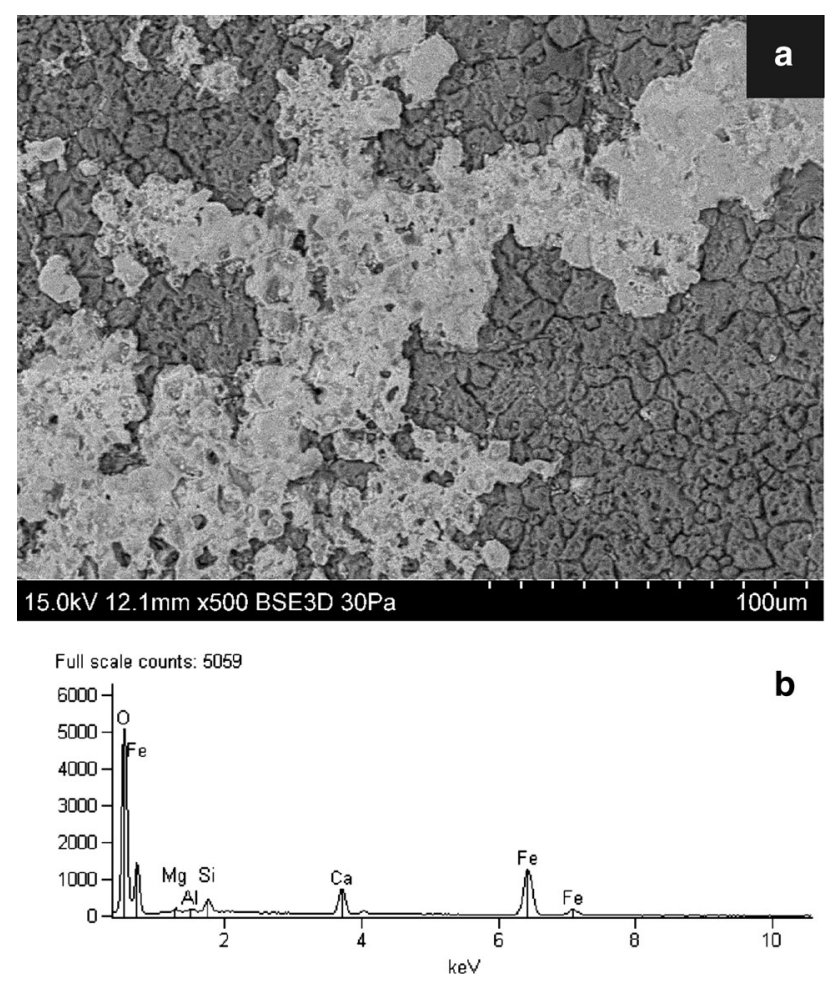

Fig. 4 a SEM image of a hematitic crust of a Frutexites shrub. b EDS spectrum of the hematitic crust. The Ca peak can be attributed to the background carbonate matrix. A slightly increased concentration of Si was found in all investigated crusts, but not in the adjacent carbonates. Most likely, this can be interpreted as a result of adsorption of silica on the precipitating iron oxides (see Konhauser 1998 and references therein) observed under cathodoluminescence, the laminated structure of type 3 can be either clear thanks to alternations of dull- and bright-luminescent units (Fig. 7h), or rather faint, with individual laminae giving mostly dull luminescence responses (Fig. 7f). In places, the last laminae of Frutexites are separated from the adjacent microsparitic sediment by a bright-luminescent rim of sparry calcitic cement (Fig. 7f).

\section{Origin of the Frutexites shrubs}

Three basic questions must be answered in order to understand the origin of the Frutexites encrustations from the Hamar Laghdad ridge: (1) What is the origin of the variety of textures and mineralogical compositions observed in Frutexites? (2) Why did Frutexites encrust "Amplexus" corallites within one single Givetian mud mound only? (3) What was the ecological relationship between the Frutexites-forming microbes and the corals? These issues require focusing on both the general settings of Frutexites-"Amplexus" associations, and the microscopic indicators of the microbial processes that were responsible for the Frutexites growth.

\section{Textural variability vs. conditions during Frutexites} formation

As indicated by various lines of geological evidence, the Givetian mud mound containing the Frutexites"Amplexus" associations developed in a deep-water, aphotic environment, in an area affected by submarine hydrothermal activity (Berkowski 2006; Jakubowicz et al. 2013). In contrast to many other deep-water Frutexites occurrences, however, the shrubs under study neither projected freely on the seafloor (cf. Woods and Baud 2008), nor encrusted the roofs of sub-seafloor cavities (cf. Reolid and Molina 2010; Lazăr et al. 2012). This reflects probably a deficiency of firm, stable substrates, which were apparently required for Frutexites columns to grow, and the available bioclasts constituted the only favorable sites for Frutexites nucleation.

As previously proposed by Böhm and Brachert (1993) for Frutexites structures in the Alpine Jurassic, the development of different growth forms of Frutexites described in the present study appears to have been controlled largely by the properties of the medium in which the shrubs grew (Fig. 8). The widespread incorporation of sediment grains and even large masses of the surrounding matrix observed within the shrubs implies clearly that type 1 Frutexites developed mostly within pore spaces of weakly consolidated micritic sediment. In contrast, the well-laminated, largely translucent type 3 Frutexites grew apparently in 

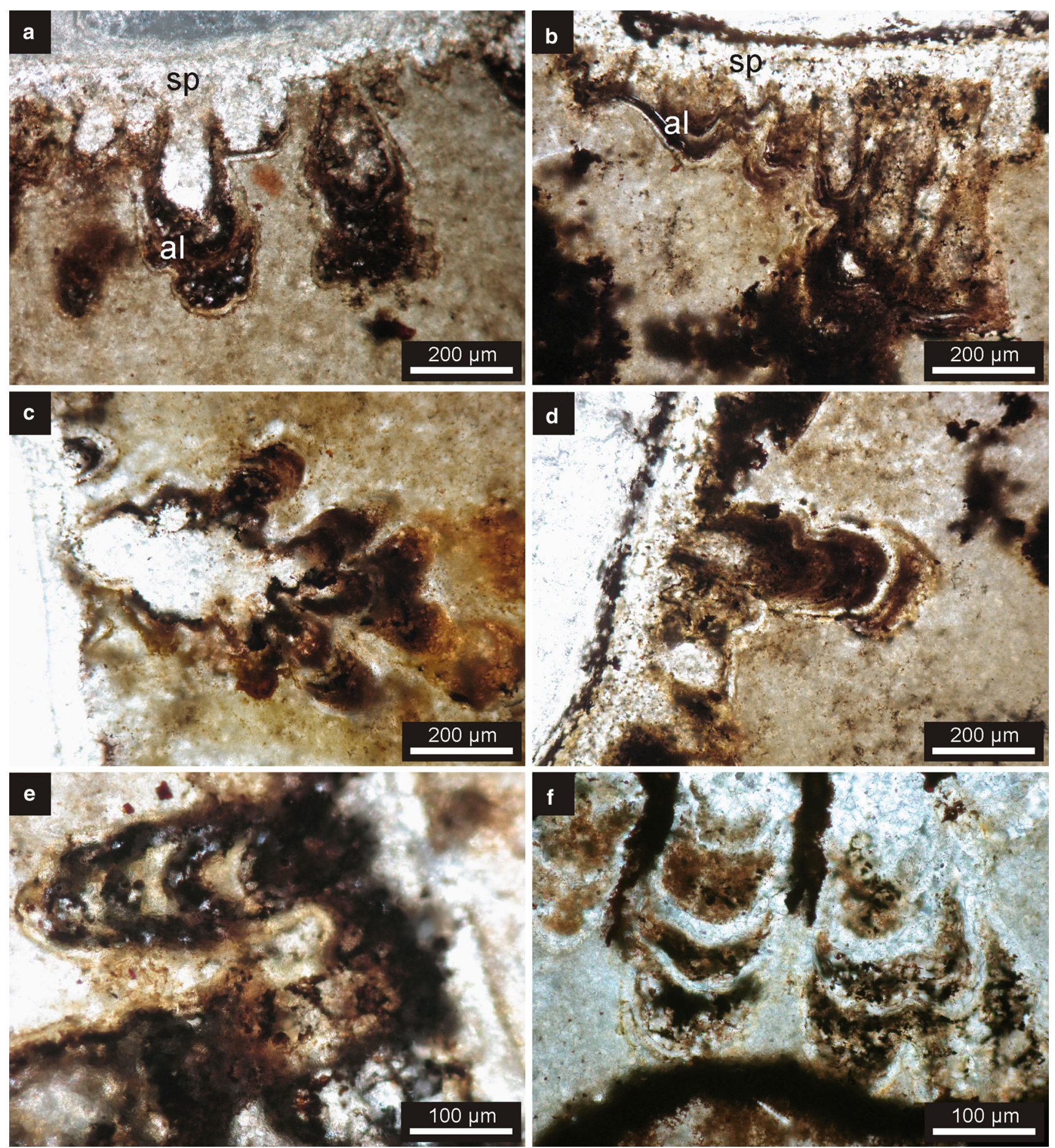

Fig. 5 Type 2 Frutexites. a, b Characteristic appearance of type 2 Frutexites. Note the presence of the initial sparry layer ( $\mathrm{sp}$ ) surrounding the corallite and forming numerous projections, followed by alternating fine hematitic and calcitic laminae (al). c Projection of the initial sparry layer with a well-defined digitate growth pattern. d Frutexites column consisting of fine alternations of hematitic and

water, either on free-standing corallites or in the interiors of sub-seafloor framework cavities (for more detailed interpretation of type 3 Frutexites, see section 'Origin of calcitic units. e, f Small Frutexites columns with well visible alternations of hematitic (black to dark-brown) and calcitic (lightbrown to colorless) laminae. The hematitic laminae may be either thinner (e) or thicker (f) than the calcitic units. Note the presence of small, spar-filled voids within the hematitic laminae

calcitic laminae'). The type 2 Frutexites columns, in turn, seem to have developed first due to free growth in water (initial sparry layer), and then to continue their accretion 

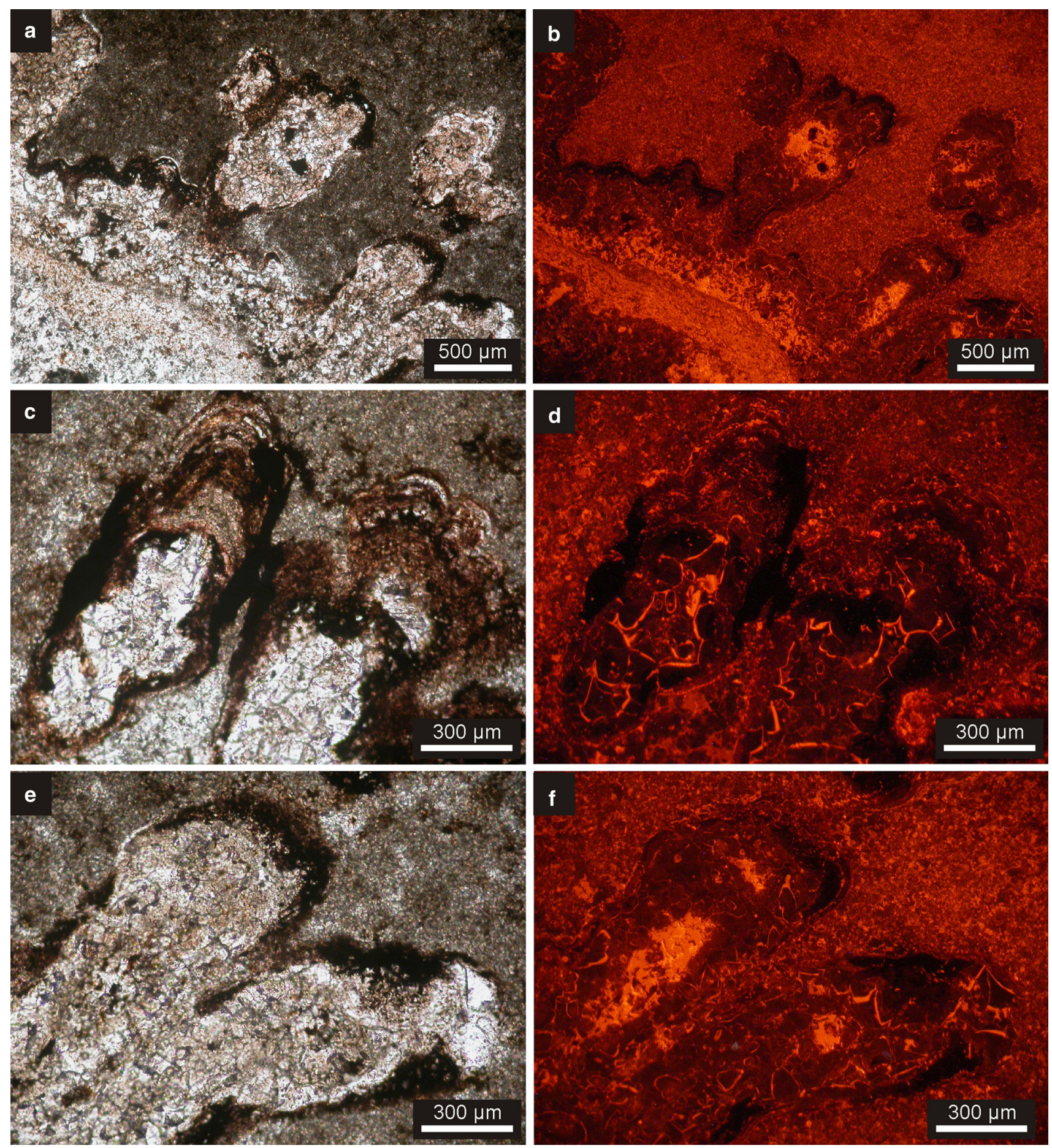

Fig. 6 Transmitted light $(\mathbf{a}, \mathbf{c}, \mathbf{e})$ and corresponding cathodoluminescence views $(\mathbf{b}, \mathbf{d}, \mathbf{f})$ of type 2 Frutexites. The secondary infilling of the initial sparry layer and its projections by rim cements is clearly visible

within the sediment (alternations of hematitic and matrixrich, calcitic laminae). This implies that while the characteristics of the medium in which Frutexites grew were of essential importance for their internal structure, they were not the main factor controlling the settlement and further activity of the Frutexites-forming microbes.
The dual nature of type 2 Frutexites, with its first layer being strikingly different from subsequent laminae in its sparry composition and lack of alternations of matrix material, appears to be of significant importance for the interpretation of the studied shrubs. Since the cathodoluminescence observations make it clear that the calcite spar 

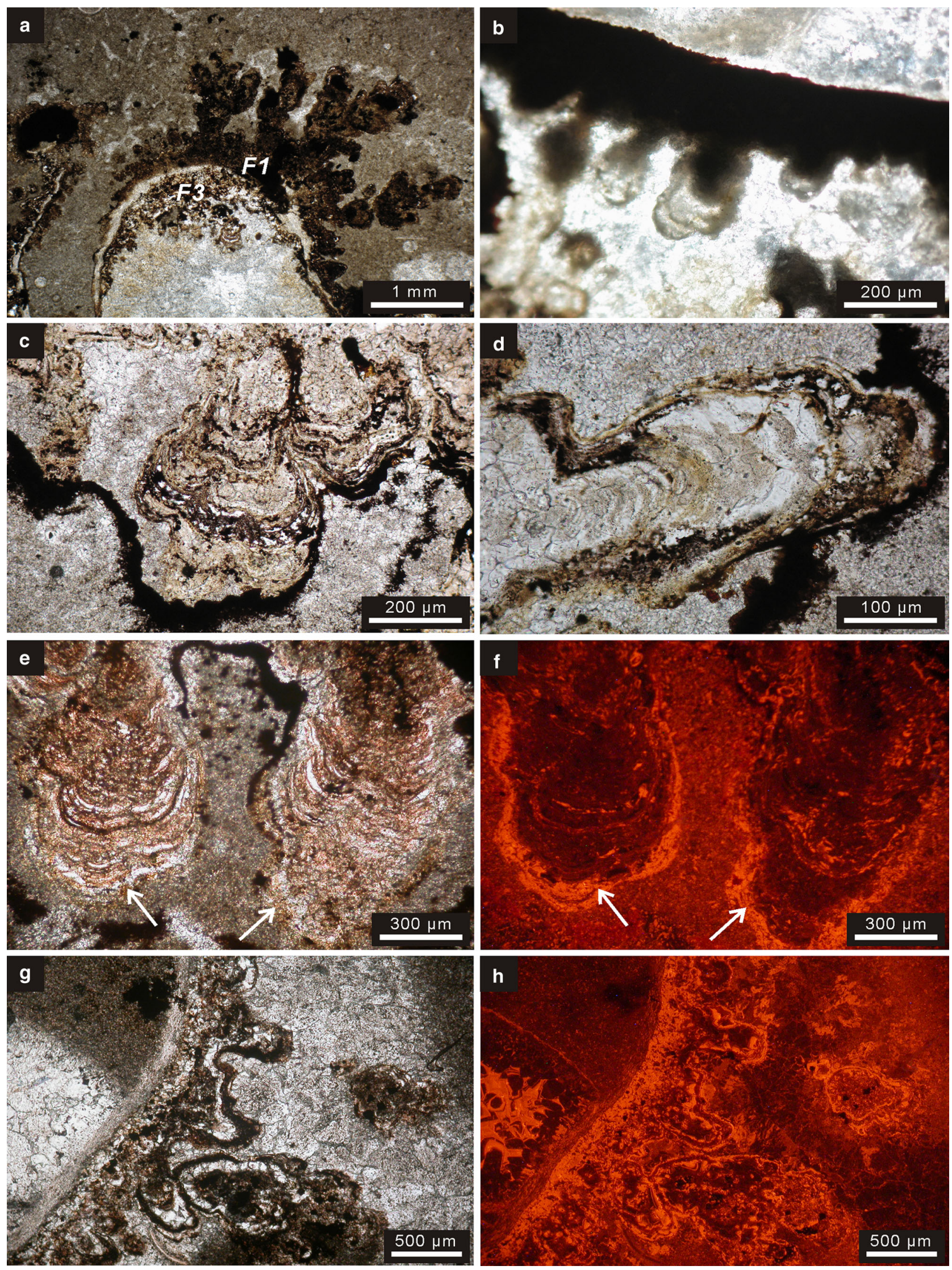
4Fig. 7 Type 3 Frutexites. a Coral fragment encrusted by type 1 Frutexites $(F 1)$ developed within the sediment, and type 3 Frutexites (F3) grown in open space. b Rare example of Frutexites with an initial layer consisting of opaque hematite. c-f Mainly calcitic Frutexites surrounded by microsparitic sediment, but lacking sediment intercalations within the laminae. Note the presence of a brightluminescent zone (arrows) surrounding the shrub (f; see e for corresponding reflected light view). $\mathbf{g}, \mathbf{h}$ Transmitted light (g) and cathodoluminescence (h) photomicrographs of Frutexites developed within a framework cavity

filled this layer by growing from the walls towards its center, the layer must occupy the space of what once constituted a pore, which became later occluded by the cements. This cementation pattern, together with the incorporation of sediment particles in the next laminae of type 2 Frutexites, indicates that the pore originated most likely from decomposition or dissolution of primary material after burial of the initial layer within the sediment. Still, the cementation of the resulting pore must have occurred relatively early during diagenesis, as the luminescence sequence of the rim cements reflects a typical transition from $\mathrm{Fe}(\mathrm{II})$ - and $\mathrm{Mn}(\mathrm{II})$-poor (non-luminescence) over $\mathrm{Mn}(\mathrm{II})$-rich ('bright window') to $\mathrm{Mn}$ (II)- and $\mathrm{Fe}$ (II)-rich (dull luminescence) carbonates associated with the decomposition of organic matter under progressive burial (e.g., Boggs and Krinsley 2006). Once buried, the microstromatolites continued their accretion by projecting into the sediment, which was probably associated with a change in composition of the microbial communities dominating the biofilms. From this time on, mineralization of the subsequently developing laminae must have been relatively rapid, as they provided a stable substrate for the growth of the rim cements after decomposition of the initial layer.

Type 1 Frutexites started growing only after burial of the "Amplexus" skeletons, as indicated by the intercalations of large portions of microspar observed in places between the shrubs and the "Amplexus" corallites, as well as by the limitation of this Frutexites type to the parts of the corallites engulfed by the microsparitic sediment. It seems that the development of well- vs. poorly defined laminations within Frutexites was controlled largely by the local properties of the sediment. As development of welllaminated stromatolites within sediment is difficult to accomplish (Verrecchia 1996), the well-laminated shrubs formed most likely only in areas (and at depths), where the sediment was poorly consolidated, whereas the presence of more compacted matrix facilitated the growth of opaque or clotted Frutexites (biodictyons sensu Krumbein et al. 2003). In fact, in many cases, the clotted appearance of type 1 Frutexites appears largely controlled not by their particular enrichment in iron oxides, but rather by the more uniform distribution of these opaque minerals than in the well-laminated Frutexites. Although the patchy distribution of calcite and hematite crystals may suggest co-

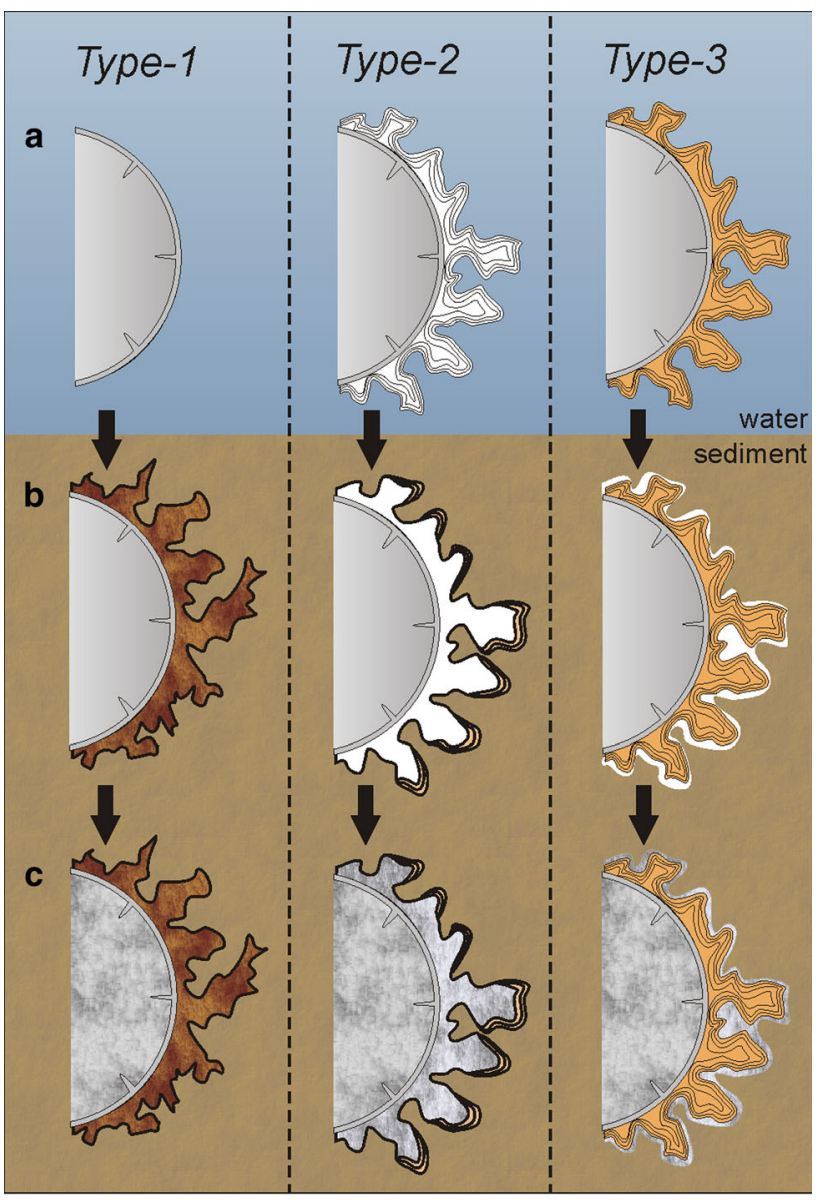

Yellowish calcite spar

Pores and non-lithified/dissolved parts of Frutexites

Alternations of hematitic and calcitic laminae

Hematite and hematite-rich calcite

Clear sparry cements

Fig. 8 Schematic stages of the development of the various Frutexites types on the "Amplexus" corallites with regard to the sediment-water interface (see text for a detailed description and interpretation). Type 1 Frutexites grew entirely after burial of the corallites within the sediment (b). Type 2 Frutexites started growing above the seafloor (a), but accretion continued within the sediment, resulting in the formation of alternating hematitic and calcitic laminae, whereas the surface-derived laminae were decomposed (b). The growth of type 3 Frutexites, in turn, occurred above the sediment-water interface (a) and came to an end by the burial of the shrubs within the sediment, which was locally marked by slight dissolution of the surrounding matrix (b). All open spaces, including the intertabular spaces of the corallites, dissolution pores, and non-lithified parts of Frutexites, became eventually filled by several generations of clear sparry (mostly early marine) cements (c)

precipitation of these minerals under the same environmental conditions, it seems most likely that they formed in somewhat different settings that developed in close proximity to each other owing to the heterogeneous character of the sediment and the associated sharp, microscale gradients in $\mathrm{pH}$ and Eh conditions during the Frutexites growth. 


\section{Possible modes of iron mineralization}

With increasing burial, degradation of organic matter is mediated by the use of progressively less energetically favorable electron acceptors, and thus commonly follows the succession: aerobic oxidation - nitrification - sulphide oxidation - nitrate reduction - Mn(IV) reduction - Fe(III) reduction - hydrolysis/fermentation - sulphate reduction $\mathrm{CO}_{2}$ reduction (Fenchel et al. 1998). In nature, however, this theoretical succession is not always followed, because the favorable path for decomposition of organic matter is influenced also by factors such as the amount and reactivity of the organic matter, the $\mathrm{pH}$ and the stability of the minerals in which the acceptors are incorporated. As a result, the various 'zones' of organic matter degradation may overlap, and theoretically less favorable electron acceptors may be consumed prior to the utilization of energetically more efficient compounds (Postma and Jakobsen 1996).

At circum-neutral $\mathrm{pH}$ and in oxygenated water, $\mathrm{Fe}^{2+}$ rapidly oxidizes to $\mathrm{Fe}^{3+}$ and is incorporated into insoluble iron oxides and hydroxides. As this reaction is abiotically controlled, the iron-oxidizing microbes in such environments must compete for $\mathrm{Fe}^{2+}$ to drive their life processes, and thus many (and the best documented) iron bacteria are acidophilic organisms (Konhauser 1998). Considering that many of the laminae building Frutexites are dominantly calcitic and thus cannot have formed at a low $\mathrm{pH}$, it was concluded that the iron-enrichment took place abiotically, due to replacement of a calcitic precursor (Myrow and Coniglio 1991; Böhm and Brachert 1993). This view does, however, not provide a satisfactory explanation for the intimate association of iron oxides with Frutexites shrubs, and, in particular, for the selective enrichment in iron oxides of some laminae. It is therefore considered here most probable that, as suggested also by others (Playford et al. 1976; Chafetz et al. 1998; Mamet and Préat 2006), the iron enrichment was a primary feature of the Frutexites microstromatolites.

Two competitive models can be proposed to account for the iron mineralization of Frutexites. In the first model, the formation of the hematitic parts of Frutexites is considered a direct result of the activity of iron-oxidizing microbes (cf. Mamet and Préat 2006; Lazăr et al. 2012). Although microbes cannot dominate the iron-oxidation processes at circum-neutral $\mathrm{pH}$ in oxidized seawater, it is now well documented that oxidation of iron can be readily mediated by neutrophilic microbes under very low oxygen conditions (Straub et al. 1996; Benz et al. 1998; Chaudhuri et al. 2001). These microaerophilic, iron-oxidizing organisms include some phototrophic and some nitrate-reducing bacteria (Frankel and Bazylinski 2003), and thus it is the process of microbial nitrate reduction that constitutes the most probable biologically mediated process of hematite precipitation in the Frutexites shrubs.

The ability to oxidize iron under anoxic conditions is a widespread property of nitrate-reducing microbes (NRB; Straub et al. 1996; Benz et al. 1998). The resulting iron minerals include typically ferrihydrite (at near-neutral $\mathrm{pH}$ rapidly oxidized to hematite; Konhauser 1998), as well as subordinate amounts of magnetite and carbonates (Straub et al. 1996). Although nitrate reduction is of only subordinate importance in the decomposition of organic matter in most marine environments, it can dominate in sediments with a high organic matter content and low bottom water oxygen concentration (Canfield et al. 1993a). Since nitrite reduction is associated with a free energy change that is significantly higher than any other anaerobic microbial redox processes (Fenchel et al. 1998), it precedes typically manganese and iron reduction (Canfield et al. 1993a, b), which is in good agreement with the cathodoluminescence pattern of type 2 Frutexites, in which precipitation of the iron-rich laminae evidently preceded the formation of nonluminescent rim cements, indicative of precipitation prior to microbial $\mathrm{Mn}(\mathrm{IV})$ and $\mathrm{Fe}(\mathrm{III})$ reduction.

According to the second model, the mineralization of the microbial biofilms with hematite (or its less stable precursor) could have occurred simply as a result of passive attraction of $\mathrm{Fe}^{2+}$ ions to the negatively charged microbial cells or cation-binding exopolymeric substances produced by microbial communities (cf. Beveridge et al. 1997; Braissant et al. 2007). At circum-neutral pH, any microbe forming exopolymeric substances may be, in fact, expected to mediate passive iron mineralization (Ghiorse 1984). In marine environments, $\mathrm{Fe}^{2+}$ ions can be liberated to sediments from various sources (e.g., Raiswell and Canfield 1998); considering the association of the studied "Amplexus" assemblages with areas of hydrothermal venting (Berkowski 2006; Jakubowicz et al. 2013), hydrothermal fluids seem to provide a particularly plausible source of excess $\mathrm{Fe}^{2+}$ ions. At modern hydrothermal vents, passive mineralization is believed to constitute the most important process of microbe encrustation with iron (Juniper and Tebo 1995; Konhauser 1998), and the relationship between hydrothermal activity and the formation of Frutexites has been previously suggested by Kazmierczak and Kempe (2006) and Reolid and Nieto (2010). $\mathrm{Fe}^{2+}$ may either have rapidly oxidized to $\mathrm{Fe}(\mathrm{III})$ during its nucleation on bacterial surfaces, thus resulting in direct precipitation of iron oxides (cf. Konhauser 1998), orunder anoxic conditions-have been incorporated into iron sulphides, and then secondarily have oxidized to oxides. The latter possibility, invoked in some earlier studies on Frutexites (Horodyski 1975; Cavalazzi et al. 2007), appears, however, less probable, as no indications of a former presence of sulphides have been found in the 
investigated samples, except for a few pyrite crystals that occur scattered within the calcitic laminae. Moreover, such a model would require a shift from iron-reducing (precipitation of sulphidic laminae) to iron-oxidizing (cementation of the first layer of type 2 Frutexites) conditions, which is not to be expected under progressive burial of Frutexites shrubs. Regardless, in the absence of data enabling identification of iron-depositing microbes, neither passive, nor active involvement of microbes in the iron mineralization of Frutexites can be favored over the other.

\section{Origin of the calcitic laminae}

The presence of yellowish (honey-colored) to orange, microsparitic to fine sparry calcitic laminae, such as those observed in the investigated Frutexites shrubs, has been reported from many other Frutexites structures (e.g., Myrow and Coniglio 1991; Böhm and Brachert 1993; Lazăr et al. 2012) and can be considered a typical feature of Frutexites. The formation of the calcitic intercalations between successive hematitic laminae can be most likely attributed to temporal changes in environmental conditions, presumably associated with concomitant changes in the composition of the microbial communities.

Most of the calcitic laminae present between hematitic crusts in type 1 and type 2 Frutexites grew within the sediment, and differ locally from the surrounding matrix only in color. Since the growth of the hematitic laminae required a rigid substrate, either the micrite incorporated in growing Frutexites must have undergone early cementation, or the substrate consisted of non-mineralized microbial structures which were subsequently dissolved. Depending upon periodical fluctuations in $\mathrm{pH}$, oxygenation and/or supply of $\mathrm{Fe}^{2+}$ ions, ferrous iron could become incorporated in precipitating carbonates (low oxygen conditions), or, after oxidation, in iron oxides (with mediation of microbes: passively under oxic conditions or actively under low oxygen conditions and lowered $\mathrm{pH}$ or increased $\mathrm{Fe}^{2+}$ supply; cf. Benz et al. 1998; Chafetz et al. 1998; Chaudhuri et al. 2001). If these environmental shifts occurred periodically, e.g., in response to variations in the influx of hydrothermal fluids and/or the supply of nutrients, they would have resulted in changes in types of microbes dominating in the surface lamina of a biofilm or in periodical mass mortalities of surface microbial communities. Possibly, the lamination may also reflect former stratification of a biofilm, with the external lamina dominated by iron-depositing bacteria, and the deeper part consisting of heterotrophic microbes inducing precipitation of calcium carbonate.

The fact that many representatives of type 3 Frutexites are closely surrounded by micritic sediments but do not contain sediment intercalations indicates that these
Frutexites formed neither within the sediment nor in small framework cavities, but rather developed on the "Amplexus" corallites when these were still projecting freely on the seafloor. As indicated by the well-defined individual laminae of type 3 Frutexites, their calcification occurred very early, in contrast to that of the type 2 shrubs, in which the initial, surface-derived layer apparently failed to calcify. Apparently, in contrast to type 2 Frutexites, the conditions favorable for cementation of the type 3 shrubs were limited to their growth on the seafloor. Perhaps, local variations in redox conditions and carbonate saturation states resulted in calcification of only some biofilms, as it is commonly observed in modern marine environments (e.g., Dupraz et al. 2009). It seems most likely that the first layer in type 2 Frutexites developed in relatively well oxygenated settings that were unfavorable for calcite precipitation, which is consistent with the mineralization of this Frutexites type taking place only after its burial within the sediment. Hence, the textural differences between the three Frutexites types seem to stem from various depths, at which the conditions conducive to formation of Frutexites occurred.

While various groups of microorganisms are theoretically capable of inducing precipitation of calcium carbonate, only cyanobacteria and some heterotrophic bacteria seem to be able to mediate extensive calcification of microbial mats and biofilms (Chafetz and Buczynski 1992; Dupraz et al. 2009). Given the aphotic environment of the Frutexites encrustations under study, the most natural candidates for facilitating the precipitation of calcite within the biofilms are heterotrophic microbes, such as nitrateand sulphate-reducing bacteria. The crucial role of nitrateand, in particular, sulphate-reducing bacteria (SRB) in the calcification of stromatolites is being increasingly appreciated, and these microbes are now recognized as playing a crucial role in the calcification of not only deep-water biofilms, but also of shallow-water, cyanobacteria-dominated mats (e.g., Chafetz and Buczynski 1992; Kempe and Kazmierczak 1994; Reid et al. 2000; Paerl et al. 2001; Braissant et al. 2007). The sulphate reduction accounts usually for more than $90 \%$ of the overall anaerobic microbial respiration, and its net result is an increase in alkalinity which, together with the production of copious amounts of exopolymeric substances by SRB, favors carbonate precipitation within a biofilm (Baumgartner et al. 2006; Dupraz et al. 2009). Although the reduction of sulphate yields little free energy, it has been evidenced that the sulphate reduction may precede Fe(III) reduction under a wide range of conditions (Postma and Jakobsen 1996), and, under specific conditions, even overlaps with nitratereduction and aerobic respiration (Teske et al. 1998). In particular, a zone of sulphate reduction can occur shallowly in the presence of high organic matter influx, 
circum-neutral $\mathrm{pH}$ and relatively stable iron oxides (such as hematite; Postma and Jakobsen 1996), and all these factors were presumably present during the development of the investigated Frutexites shrubs. The activity of heterotrophic microbes can consequently well explain the observed cathodoluminescence pattern of type 3 Frutexites, which indicates that most of the laminae formed prior to microbial $\mathrm{Mn}(\mathrm{IV})$ and $\mathrm{Fe}(\mathrm{III})$ reduction.

As SRB are typically limited to low-oxygen conditions, their hypothetical involvement in the formation of Frutexites is consistent with the suggested affinity of Frutexites-forming microbes to poorly oxygenated, stagnant water settings. The presence of SRB is, however, not necessarily indicative of strictly anoxic bottom water, as they may have thrived under microaerophylic conditions that were present within the biofilm consisting of various microbial communities in an otherwise oxic environment (cf. Okabe et al. 1999; Baumgartner et al. 2006). The involvement of SRB seems also to be consistent with the numerous finds of filamentous structures in calcitic laminae of Frutexites that were occasionally attributed to cyanobacteria (Maslov 1960; Walter and Awramik 1979), as filamentous growth forms are found among sulphatereducing microbes as well (Fukui et al. 1999). Finally, the widespread activity of heterotrophic microbes mediating decomposition of organic matter is confirmed by the $\delta^{13} \mathrm{C}$ values measured in the Frutexites-bearing carbonates, which are consistently approximately 1.5-4.5\%o PDB lower than the signatures found in the adjacent, but Frutexites-lacking "Amplexus"-rich deposits within the Givetian mound (Jakubowicz et al. 2013). Analogous trends in depleted $\delta^{13} \mathrm{C}$ values have been previously reported from Frutexites-bearing carbonates by Kazmierczak and Kempe (2006), as well as from calcitic (renalcid) microstromatolites by Stephens and Sumner (2002).

Cavalazzi et al. (2007) came to a similar conclusion regarding the importance of sulphate reduction in the formation of Frutexites. They suggested, however, that SRB directly mediated the formation of iron-rich laminae by precipitating iron sulphides, which would be subsequently oxidized to hematite. Indeed, production of sulphide by SRB may account for the slight dissolution of the matrix surrounding some of the Frutexites columns. A primarily sulphidic composition of the hematitic laminae in the studied shrubs appears nevertheless, as detailed above, of little probability. Perhaps, this might be explained by the fact that $\mathrm{Fe}^{2+}$ ions are under alkaline conditions preferentially incorporated into carbonates (e.g., Chaudhuri et al. 2001), which could have prevented more extensive precipitation of sulphide minerals. Moreover, in organic-rich sediments with high sulphate reduction rates only a small percentage of the $\mathrm{HS}^{-}$that is produced becomes incorporated into sulphides, whereas the remnant often diffuses upwards and becomes re-oxidized to sulphate (e.g., Okabe et al. 1999). Thus, sulphate reduction results typically in the formation of scattered sulphide crystals, such as those present in the calcitic intervals, rather than in the development of well-defined sulphidic laminae. It seems, therefore, most likely that the hematite-calcite alternations precipitated either due to the activity of sulphate- (calcitedepositing) and nitrate-reducing (iron-depositing) microbes, or due to periodical passive mineralization of SRB-containing microbial communities with iron minerals (cf. Braissant et al. 2007).

Paleoecology of the Frutexites-forming microbes and their relationship to "Amplexus" corals

A high input of organic matter from decaying coral tissues, an increased supply of $\mathrm{Fe}^{2+}$ ions, and a harsh environment that excluded most eukaryotes seem to have been the most important factors that enabled the development of Frutexites-forming microbial communities in the studied "Amplexus" assemblages. In the absence of any of these conditions, the growth of Frutexites was apparently hampered, as shown by the lack of Frutexites in any other Pragian to Givetian "Amplexus" occurrences scattered throughout the Hamar Laghdad area (Jakubowicz et al. 2013).

The common occurrences of Frutexites-rich and Frutexites-free "Amplexus" assemblages in close proximity to each other within the Givetian mud mound indicates that the environmental conditions differed considerably from place to place, even at a small scale. Because Frutexites seem to have preferred low-oxygen settings, the areas without shrubs were presumably characterized by a relatively high dissolved oxygen content. This is supported by the total absence of well-developed Frutexites shrubs where radiaxial fibrous cements are present, indicating increased water circulation. Considering the association of the "Amplexus" assemblages with discharges of hydrothermal fluids (Berkowski 2006; Jakubowicz et al. 2013), it may be suggested that the areas experiencing relatively vigorous fluid flow were also places of increased mixing between the reducing hydrothermal fluids and oxygenated seawater, as is the case around modern submarine fluid emissions (O'Hara et al. 1995). Hence, although the microbes encrusted some of the "Amplexus" corallites also in places of intensive fluid flow, resulting in the formation of thin iron-rich crusts, in such areas the microbial communities were apparently unable to form well-developed shrubs. The development of Frutexites was therefore probably restricted to areas characterized by a relatively slow and diffuse fluid flow, resulting in the development of better defined redox zonation (cf. Han et al. 2004), favoring the activity of anaerobic heterotrophic microbes. 
The question of whether the Frutexites shrubs developed on the corallites when the corals were still alive or only after their death, is somewhat difficult to answer. Due to their scolecoid shapes and shallow calices, the "Amplexus" polyps occupied only the uppermost parts of their corallites, so that large parts of the skeletons were essentially 'dead' even during life of the corals. Since major parts of the corallites were embedded in the sediment, type 1 Frutexites could thus very well have encrusted the corallites still inhabited by the corals. Although "Amplexus" represented probably an opportunistic species adapted to low oxygen availability (Jakubowicz et al. 2013), it appears unlikely that Frutexites could have encrusted also the uppermost parts of the skeletons of living "Amplexus" corals, since no indications of direct interactions between the corals and Frutexites-forming microbes have been found in the investigated associations, and, in particular, the encrustations never continue in places where two corallites adhered to each other. Hence, those Frutexites that developed above the seafloor must have either colonized abandoned corallites or grown immediately above the sediment-water interface. That Frutexites never occur on the internal corallite walls except for a few broken corallites can be presumably explained by an insufficient supply of nutrients to the isolated calices and intertabular spaces, as water circulation in these places must have been considerably more restricted than in the surrounding soft, unconsolidated sediment. The interiors of unbroken corallites constituted therefore unfavorable places for the development of Frutexites.

\section{Formation of Frutexites: a model}

In conclusion, a schematic model for the development of the Frutexites shrubs on "Amplexus" corals that lived in places affected by hydrothermal venting at Hamar Laghdad can be proposed:

1. In places where the fluid flow rate was relatively low, enabling the development of a stable, shallow anoxic zone, "Amplexus" corallites were colonized by nonphototrophic microbial communities. The microbes were likely attracted by the increased production of organic matter, the supply of metabolic substrates $\left(\mathrm{Fe}^{2+}\right)$ and the decreased activity of eukaryotes. Accretion of the biofilms under periodically and spatially variable environmental conditions resulted in the formation of the irregular Frutexites shrubs, consisting of alternations of calcitic and hematitic laminae.

2. The presence of both hematitic and calcitic laminae was a primary feature of Frutexites. Iron enrichment occurred either due to the activity of nitrate-reducing microbes, or due to passive mineralization of microbial communities with iron. Calcite laminae, in turn, formed most likely as a result of increased activity of sulphate-reducing microbes. The variations in domination of extracellular polymeric substances of different microbial communities were presumably caused by variations in $\mathrm{pH}, \mathrm{Fe}^{2+}$ supply and/or oxygenation during biofilm accretion. To some extent, the presence of lamination may also reflect the primary tiering of the biofilm.

3. Spatial and temporal variations of the redox conditions resulted in differences in the timing of formation of the various types of Frutexites shrubs. This led to development of a continuous spectrum of Frutexites textures, among which three basic types can be distinguished. These Frutexites types are macroscopically similar, but differ significantly in microstructure and genesis. Type 1 Frutexites grew entirely within the sediment; its 'clotted' appearance with poorly developed lamination resulted from the growth within the heterogeneous substratum with sharp micro-scale gradients in environmental conditions. Type 2 Frutexites started accretion above the seafloor and continued to grow within the sediment, although the surface-derived layer was decomposed after burial. Type 3 Frutexites, in turn, built by well-defined, mostly calcitic laminae, developed entirely above the seafloor or within cavities, and their growth ceased after burial within the sediment.

4. The surface-derived layers of type 2 Frutexites decomposed after burial and encrustation by hematitic and calcitic laminae; the resulting voids were subsequently filled with calcitic rim cements. The luminescence pattern of the cements reflects the transition from neither $\mathrm{Mn}(\mathrm{IV})$ nor $\mathrm{Fe}(\mathrm{III})$-reducing, over $\mathrm{Mn}(\mathrm{IV})$-reducing, to $\mathrm{Fe}(\mathrm{III})$ reducing conditions. This indicates that the sulphate and nitrate reduction in Frutexites under study preceded the Mn(IV) and $\mathrm{Fe}(\mathrm{III})$ reduction, most likely due to the high influx of organic matter and the high stability of the iron oxides present (probably rapidly converted to hematite).

5. Frutexites either encrusted the corallites after death of the corals, or colonized lower parts of the skeletons, possibly when the coral was still alive. Since there are no indications for interactions between the corals and the encrusting microbes, however, it appears that the polyps and the microbes did not live contemporaneously under the same range of environmental conditions, and that the settings favorable for coral growth differed (e.g., in oxygen availability) from those that facilitated Frutexites development. 
Acknowledgments The authors wish to thank Abdelali Mjid and Echerqui Rjimati (both Ministère de 1'Energie, des Mines, de l'Eau et de l'Environnement, Morocco) for the work permit and logistic advice. The present study was supported by the Polish Ministry of Science and Higher Education (Grant Nr. N307 016237). The authors are indebted to Z. Mlynarczyk (Adam Mickiewicz University) for logistic help, and to J. Biernacka, A. Duczmal-Czernikiewicz, M. Mrozek-Wysocka (Adam Mickiewicz University), and P. Raczynski (University of Wroclaw) for their help and stimulating discussions during microscopic investigations. A.J. (Tom) Van Loon (Adam Mickiewicz University) kindly improved the English of the paper. A.J. Kazmierczak (Polish Academy of Sciences) is gratefully acknowledged for his valuable comments on an earlier draft of the manuscript. The manuscript has benefited from thorough revisions by M. Reolid (University of Jaén) and an anonymous reviewer.

Open Access This article is distributed under the terms of the Creative Commons Attribution License which permits any use, distribution, and reproduction in any medium, provided the original author(s) and the source are credited.

\section{References}

Aitken SA, Collom CJ, Henderson CM, Johnston PA (2002) Stratigraphy, paleoecology, and origin of Lower Devonian (Emsian) carbonate mud buildups, Hamar Laghdad, eastern Anti-Atlas, Morocco, Africa. Bull Can Petrol Geol 50:217-243

Baumgartner LK, Reid RP, Dupraz C, Decho AW, Buckley DH, Spear JR, Przekop KM, Visscher PT (2006) Sulfate reducing bacteria in microbial mats: changing paradigms, new discoveries. Sediment Geol 185:131-145. doi:10.1016/j.sedgeo.2005.12. 008

Belka Z (1991) Conodont alteration patterns in Devonian rocks of the eastern Anti-Atlas, Morocco. J Afr Earth Sci 12:417-428. doi:10.1016/0899-5362(91)90133-J

Belka Z (1998) Early Devonian Kess-Kess carbonate mud mounds of the eastern Anti-Atlas (Morocco), and their relation to submarine hydrothermal venting. J Sediment Res 68:368-377

Belka Z, Berkowski B (2005) Discovery of thermophilic corals in an ancient hydrothermal vent community, Devonian, Morocco. Acta Geol Polon 55:1-7

Belka Z, Kazmierczak M, Kaufmann B (1997) Tectonic control on the sedimentation, volcanic activity and the growth of mud mounds in the Palaeozoic of the eastern Anti-Atlas, Morocco. Paper presented at the First International Conference on North Gondwanan Mid-Palaeozoic Biodynamics (IGCP Project 421), Vienna, 17-21 September 1997

Benz M, Brune A, Schink B (1998) Anaerobic and aerobic oxidation of ferrous iron at neutral $\mathrm{pH}$ by chemoheterotrophic nitratereducing bacteria. Arch Microbiol 169:159-165. doi:10.1007/ s002030050555

Berkowski B (2004) Monospecific rugosan assemblage from the Emsian hydrothermal vents of Morocco. Acta Palaeont Polon 49:75-84

Berkowski B (2006) Vent and mound rugose coral associations from the Middle Devonian of Hamar Laghdad (Anti-Atlas, Morocco). Geobios 39:155-170. doi:10.1016/j.geobios.2004.11.003

Beveridge TJ, Makin SA, Kadurugamuwa JL, Li ZS (1997) Interactions between biofilms and the environment. FEMS Microbiol Rev 20:291-303. doi:10.1111/j.1574-6976.1997.tb00315.x

Boggs S, Krinsley D (2006) Application of cathodoluminescence imaging to the study of sedimentary rocks. Cambridge University Press, New York
Böhm F, Brachert TC (1993) Deep-water stromatolites and Frutexites Maslov from the Early and Middle Jurassic of S-Germany and Austria. Facies 28:145-168

Brachert TC, Buggisch W, Flugel E, Hüssner HM, Joachimski MM, Tourneur F, Walliser OH (1992) Controls of mud mound formation-the Early Devonian Kess-Kess carbonates of the Hamar Laghdad, Antiatlas, Morocco. Geol Rundsch 81:15-44

Braissant O, Decho AW, Dupraz C, Glunk C, Przekop KM, Visscher PT (2007) Exopolymeric substances of sulfate-reducing bacteria: interactions with calcium at alkaline $\mathrm{pH}$ and implication for formation of carbonate minerals. Geobiology 5:401-411. doi:10. 1111/j.1472-4669.2007.00117.x

Buczynski C, Chafetz HS (1991) Habit of bacterially induced precipitates of calcium carbonate and the influence of medium viscosity on mineralogy. J Sediment Petrol 61:226-233

Canfield DE, Jorgensen BB, Fossing H, Glud R, Gundersen J, Ramsing NB, Thamdrup B, Hansen JW, Nielsen LP, Hall POJ (1993a) Pathways of organic carbon oxidation in 3 continental margin sediments. Mar Geol 113:27-40. doi:10.1016/00253227(93)90147-n

Canfield DE, Thamdrup B, Hansen JW (1993b) The anaerobic degradation of organic matter in Danish coastal sediments-iron reduction, manganese reduction, and sulfate reduction. Geochim Cosmochim Acta 57:3867-3883. doi:10.1016/00167037(93)90340-3

Cavalazzi B, Barbieri R, Ori GG (2007) Chemosynthetic microbialites in the Devonian carbonate mounds of Hamar Laghdad (Anti-Atlas, Morocco). Sediment Geol 200:73-88. doi:10.1016/j. sedgeo.2007.03.002

Chafetz HS, Folk RL (1984) Travertines-depositional morphology and the bacterially constructed constituents. J Sediment Petrol 54:289-316

Chafetz HS, Buczynski C (1992) Bacterially induced lithification of microbial mats. Palaios 7(3):277-293. doi:10.2307/3514973

Chafetz HS, Guidry SA (1999) Bacterial shrubs, crystal shrubs, and ray-crystal shrubs: bacterial vs. abiotic precipitation. Sediment Geol 126:57-74. doi:10.1016/s0037-0738(99)00032-9

Chafetz HS, Akdim B, Julia R, Reid A (1998) Mn- and Fe-rich black travertine shrubs: bacterially (and nanobacterially) induced precipitates. J Sediment Res 68:404-412

Chaudhuri SK, Lack JG, Coates JD (2001) Biogenic magnetite formation through anaerobic biooxidation of $\mathrm{Fe}(\mathrm{II})$. Appl Environ Microbiol 67:2844-2848. doi:10.1128/AEM.67.6. 2844-2848.2001

Dupraz C, Reid RP, Braissant O, Decho AW, Norman RS, Visscher PT (2009) Processes of carbonate precipitation in modern microbial mats. Earth Sci Rev 96:141-162. doi:10.1016/j. earscirev.2008.10.005

Fenchel T, Blackburn H, King GM (1998) Bacterial biogeochemistry: the ecophysiology of mineral cycling. Academic Press, San Diego

Frankel RB, Bazylinski DA (2003) Biologically induced mineralization by bacteria. Rev Miner Geochem 54:217-247

Fukui M, Teske A, Assmus B, Muyzer G, Widdel F (1999) Physiology, phylogenetic relationships, and ecology of filamentous sulfate-reducing bacteria (genus Desulfonema). Arch Microbiol 172:193-203. doi:10.1007/s002030050760

Ghiorse WC (1984) Biology of iron-depositing and manganesedepositing bacteria. Annu Rev Microbiol 38:515-550. doi:10. 1146/annurev.micro.38.1.515

Guo L, Riding R (1992) Microbial micritic carbonates in uppermost Permian reefs, Sichuan Basin, southern China-some similarities with recent travertines. Sedimentology 39:37-53. doi:10. 1111/j.1365-3091.1992.tb01022.x

Han X, Suess E, Sahling H, Wallmann K (2004) Fluid venting activity on the Costa Rica margin: new results from authigenic 
carbonates. Int J Earth Sci 93:596-611. doi:10.1007/s00531-0040402-y

Hofmann HJ (1969) Stromatolites from the Proterozoic Animikie and Sibley groups, Ontario. Geol Surv Canada Pap 68-69:1-77

Horodyski RJ (1975) Stromatolites of the Lower Missoula Group (Middle Proterozoic), Belt Supergroup, Glacier National Park, Montana. Precambrian Res 2:215-254. doi:10.1016/03019268(75)90010-8

Jakubowicz M, Berkowski B, Belka Z (2013) Devonian rugose coral 'Amplexus' and its relation to submarine fluid seepage. Palaeogeogr Palaeoclimatol Palaeoecol 386:180-193. doi:10.1016/j. palaeo.2013.05.020

Juniper SK, Tebo BM (1995) Microbe-metal interactions and mineral deposition at hydrothermal vents. In: Karl DM (ed) The microbiology of deep-sea hydrothermal vents. CRC Press, Boca Raton, pp 219-253

Kazmierczak J, Kempe S (2006) Genuine modern analogues of Precambrian stromatolites from caldera lakes of Niuafo'ou Island, Tonga. Naturwissenschaften 93:119-126. doi:10.1007/ s00114-005-0066-x

Kazmierczak J, Kempe S, Kremer B, López-García P, Moreira D, Tavera R (2011) Hydrochemistry and microbialites of the alkaline crater lake Alchichica, Mexico. Facies 57:543-570. doi:10.1007/s10347-010-0255-8

Kempe S, Kazmierczak J (1994) The role of alkalinity in the evolution of ocean chemistry, organization of living systems, and biocalcification processes. Bull Inst Oceanogr Spec Issue 13:61-117

Konhauser KO (1998) Diversity of bacterial iron mineralization. Earth Sci Rev 43:91-121. doi:10.1016/s0012-8252(97)00036-6

Krumbein WE, Brehm U, Gierdes G, Gorbushina AA, Levit G, Palinska K (2003) Biofilm, biodictyon, biomat microbialites, oolites, stromatolites, geophysiology, global mechanism, parahistology. In: Krumbein WE, Paterson DM, Zavarzin GA (eds) Fossil and recent biofilms: a natural history of life on earth. Kluwer Academic Publishers, Dordrecht, pp 1-28

Lazăr I, Grădinaru M, Petrescu L (2012) Ferruginous microstromatolites related to Middle Jurassic condensed sequences and hardgrounds (Bucegi Mountains, Southern Carpathians, Romania). Facies 59:359-390. doi:10.1007/s10347-012-0313-5

Mamet B, Préat A (2006) Iron-bacterial mediation in Phanerozoic red limestones: state of the art. Sediment Geol 185:147-157. doi:10. 1016/j.sedgeo.2005.12.009

Mamet B, Préat A, DeRidder C (1997) Bacterial origin of the red pigmentation in the Devonian Slivenec Limestone, Czech Republic. Facies 36:173-187. doi:10.1007/bf02536883

Maslov VP (1960) Stromatolity. Trudy Geol Inst Akad Nauk SSSR 41:1-188

Mišík M, Aubrecht R (2004) Some notes concerning mineralized hardgrounds (Jurassic and Cretaceous, Western Carpathians). Were all hardgrounds always hard from the beginning? Slovak Geol Mag 10:183-202

Mounji D, Bourque PA, Savard MM (1998) Hydrothermal origin of Devonian conical mounds (kess-kess) of Hamar Lakhdad Ridge, Anti-Atlas, Morocco. Geology 26:1123-1126. doi:10.1130/ 0091-7613(1998)026<1123:hoodcm >2.3.co;2

Myrow PM, Coniglio M (1991) Origin and diagenesis of cryptobiontic Frutexites in the Chapel Island Formation (Vendian to Early Cambrian) of southeast Newfoundland, Canada. Palaios 6:572-585. doi: $10.2307 / 3514920$

Nicoll RS, Playford PE (1993) Upper Devonian iridium anomalies, conodont zonation and the Frasnian-Famennian boundary in the Canning Basin, Western Australia. Palaeogeogr Palaeoclimatol Palaeoecol 104:105-113. doi:10.1016/0031-0182(93)90123-Z

O'Hara SCM, Dando PR, Schuster U, Bennis A, Boyle JD, Chui FTW, Hatherell TVJ, Niven SJ, Taylor LJ (1995) Gas seep induced interstitial water circulation-observations and environmental implications. Continent Shelf Res 15:931-948. doi:10. 1016/0278-4343(94)00050-w

Okabe S, Itoh T, Satoh H, Watanabe Y (1999) Analyses of spatial distributions of sulfate-reducing bacteria and their activity in aerobic wastewater biofilms. Appl Environ Microbiol 65:5107-5116

Olempska E, Belka Z (2010) Hydrothermal vent myodocopid ostracods from the Eifelian (Middle Devonian) of southern Morocco. Geobios 43:519-529. doi:10.1016/j.geobios.2010.06.001

Olivier N, Colombié C, Pittet B, Lathuilière B (2011) Microbial carbonates and corals on the marginal French Jura platform (Late Oxfordian, Molinges section). Facies 57:469-492. doi:10.1007/ s10347-010-0246-9

Paerl HW, Steppe TF, Reid RP (2001) Bacterially mediated precipitation in marine stromatolites. Environ Microbiol 3:123-130. doi:10.1046/j.1462-2920.2001.00168.x

Peckmann J, Walliser OH, Riegel W, Reitner J (1999) Signatures of hydrocarbon venting in a Middle Devonian carbonate mound (Hollard Mound) at the Hamar Laghdad (Antiatlas, Morocco). Facies 40:281-296. doi:10.1007/bf02537477

Playford PE, Cockbain AE, Druce EC, Wray JL (1976) Devonian stromatolites from the Canning Basin, Western Australia. In: Walter MR (ed) Stromatolites. Developm Sediment 20:543-563. doi:10.1016/S0070-4571(08)71158-0

Postma D, Jakobsen R (1996) Redox zonation: equilibrium constraints on the $\mathrm{Fe}(\mathrm{III}) / \mathrm{SO}_{4}$-reduction interface. Geochim Cosmochim Acta 60:3169-3175. doi:10.1016/0016-7037(96)00156-1

Pratt BR (1984) Epiphyton and Relalcis-diagenetic microfossils from calcification of coccoid blue-green-algae. J Sediment Petrol 54:948-971

Préat A, El Hassani A, Mamet B (2008) Iron bacteria in Devonian carbonates (Tafilalt, Anti-Atlas, Morocco). Facies 54:107-120. doi:10.1007/s10347-007-0124-2

Raiswell R, Canfield DE (1998) Sources of iron for pyrite formation in marine sediments. Am J Sci 298:219-245

Reid RP, Visscher PT, Decho AW, Stolz JF, Bebout BM, Dupraz C, Macintyre LG, Paerl HW, Pinckney JL, Prufert-Bebout L, Steppe TF, DesMarais DJ (2000) The role of microbes in accretion, lamination and early lithification of modern marine stromatolites. Nature 406:989-992

Reitner J, Wilmsen M, Neuweiler F (1995) Cenomanian/Turonian sponge microbialite deep-water hardground community (Liencres, northern Spain). Facies 32:203-212. doi:10.1007/ bf02536869

Reolid M (2011) Palaeoenvironmental contexts for microbial communities from $\mathrm{Fe}-\mathrm{Mn}$ crusts of Middle-Upper Jurassic hardgrounds (Betic-Rifian Cordillera). Rev Españ Paleont 26:135-160

Reolid M, Molina JM (2010) Serpulid-Frutexites assemblage from shadow-cryptic environments in Jurassic marine caves, Betic Cordillera, southern Spain. Palaios 25:468-474. doi:10.2110/ palo.2009.p09-150r

Reolid M, Nieto LM (2010) Jurassic Fe-Mn macro-oncoids from pelagic swells of the External Subbetic (Spain): evidences of microbial origin. Geol Acta 8:151-168. doi:10.1344/105. 000001525

Riding R (2000) Microbial carbonates: the geological record of calcified bacterial-algal mats and biofilms. Sedimentology 47:179-214. doi:10.1046/j.1365-3091.2000.00003.x

Rodríguez-Martínez M, Heim C, Quéric N-V, Reitner J (2011a) Frutexites. In: Reitner J, Thiel V (eds) Encyclopedia of Geobiology. Springer, Berlin, pp 396-401

Rodríguez-Martínez M, Heim C, Simon K, Zilla T, Reitner J (2011b) Tolypammina gregaria Wendt 1969-Frutexites assemblage and ferromanganese crusts: a coupled nutrient-metal interplay in the 
Carnian sedimentary condensed record of Hallstatt facies (Austria). In: Reitner J, Queric N-V, Arp G (eds) Advances in stromatolite geobiology. Lecture Notes Earth Sci 131:409-434. doi:10.1007/978-3-642-10415-2_25

Stanley GD Jr, Cairns SD (1988) Constructional azooxanthellate coral communities: an overview with implications for the fossil record. Palaios 3:233-242

Stephens NP, Sumner DY (2002) Renalcids as fossilized biofilm clusters. Palaios 17:225-236. doi:10.1669/0883-1351(2002)017 $<0225$ :rafbc $>2.0$. co; 2

Straub KL, Benz M, Schink B, Widdel F (1996) Anaerobic, nitratedependent microbial oxidation of ferrous iron. Appl Environ Microbiol 62:1458-1460

Szulczewski M (1963) Stromatolites from the high-tatric Bathonian of the Tatra Mountains. Acta Geol Polon 13:125-141

Teske A, Ramsing NB, Habicht K, Fukui M, Kuver J, Jorgensen BB, Cohen Y (1998) Sulfate-reducing bacteria and their activities in cyanobacterial mats of Solar Lake (Sinai, Egypt). Appl Environ Microbiol 64:2943-2951

Tsien HH (1979) Paleoecology of algal-bearing facies in the Devonian (Couvinian to Frasnian) reef complexes of Belgium. Palaeogeogr Palaeoclimatol Palaeoecol 27:103-127
Verrecchia EP (1996) Morphometry of microstromatolites in calcrete laminar crusts and a fractal model of their growth. Math Geol 28:87-109. doi:10.1007/bf02273525

Walter MR, Awramik SM (1979) Frutexites from stromatolites of the Gunflint Iron Formation of Canada, and its biological affinities. Precambrian Res 9:23-33. doi:10.1016/0301-9268(79)90049-4

Wendt J (1970) Stratigraphische Kondensation in triadischen und jurassischen Cephalopodenkalken der Tethys. N Jb Geol Paläont Mh 1970:433-449

Wendt J (1985) Disintegration of the continental margin of northwestern Gondwana: Late Devonian of the eastern AntiAtlas (Morocco). Geology 13:815-818. doi:10.1130/00917613(1985) $13<815$ :dotcmo $>2.0 . c 0 ; 2$

Woods AD, Baud A (2008) Anachronistic facies from a drowned Lower Triassic carbonate platform: lower member of the Alwa Formation (Ba'id Exotic), Oman Mountains. Sediment Geol 209:1-14. doi:10.1016/j.sedgeo.2008.06.002 